\title{
Occurrence and risk factors for falls in adults with rheumatoid arthritis: a systematic review
}

\author{
Angela Brenton-Rule ${ }^{1 *}$, Keith Rome ${ }^{1}$, Nicola Dalbeth ${ }^{2}$ \\ From Australasian Podiatry Council Conference 2013 \\ Sydney, Australia. 2-5 June 2013
}

\section{Background}

Rheumatoid arthritis (RA) is a chronic, inflammatory disease characterised by progressive joint destruction. Foot involvement is common in RA and the podiatrist is an important member of the multidisciplinary healthcare team. People with RA, of all ages, experience frequent falls and may be at greater risk of falling than the nonRA population. Falls are complex, resulting from intrinsic, behavioural and environmental risk factors. The aim of the review was to determine the occurrence and risk factors for falls in people with RA.

\section{Methods}

A search was conducted during July and November 2012 using AMED, CINAHL, Medline, Scopus and Cochrane Library online databases. All articles were obtained from English-language peer reviewed scientific journals. To be eligible for the review a study had to include adults with diagnosed RA and have falls as a primary or secondary outcome measure.

\section{Results}

Ten articles were identified for review. Falls incidence, over a 12 month period, ranged between 27 and 50\%. Six studies evaluated potential falls risk factors. Falls were associated with decreased walking speed and standing balance, increased disease activity, co-morbid conditions, medications and fall history. Foot deformity was evaluated in only one study and found not to be associated with falls in RA.

\footnotetext{
* Correspondence: abrenton@aut.ac.nz

${ }^{1}$ Health and Rehabilitation Research Institute, AUT University, Auckland, New Zealand
}

Full list of author information is available at the end of the article

\section{Conclusion}

Falls in this already vulnerable group can be devastating and falls prevention is vital to the podiatric management of the RA patient. An awareness of the risk factors associated with falls in RA may help podiatrists to identify and better manage patients with increased falls risk.

\section{Author details}

${ }^{1}$ Health and Rehabilitation Research Institute, AUT University, Auckland, New Zealand. ${ }^{2}$ University of Auckland, Auckland, New Zealand.

Published: 31 May 2013

\section{doi:10.1186/1757-1146-6-S1-O2}

Cite this article as: Brenton-Rule et al:: Occurrence and risk factors for falls in adults with rheumatoid arthritis: a systematic review. Journal of Foot and Ankle Research 2013 6(Suppl 1):O2.

\section{Submit your next manuscript to BioMed Central and take full advantage of: \\ - Convenient online submission \\ - Thorough peer review \\ - No space constraints or color figure charges \\ - Immediate publication on acceptance \\ - Inclusion in PubMed, CAS, Scopus and Google Scholar \\ - Research which is freely available for redistribution \\ Submit your manuscript at

